\title{
Evaluation of Phytotoxicity of Diazinon and Captan Formulations on Highbush Blueberries
}

\author{
Sridhar Polavarapu
}

AdDitional INDEX WORDS. highbush blueberries, Vaccinium corymbosum, phenology, phytotoxicity, fruit injury, leaf injury, diazinon, captan

Summary. A common practice in highbush blueberry (Vaccinium corymbosum L.) culture is to use combinations of insecticides and fungicides to reduce the number and cost of pesticide applications. In response to apparent phytotoxicity observed in commercial fields that were treated with combinations of diazinon and captan formulations, phytotoxicity of two formulations of diazinon (D iazinon A G 600 and D iazinon 50W) and captan (C aptan 80WP and ( aptec 4L) was investigated on highbush blueberries during 1997 and 1998. Phytotoxicity injury similar to injury observed in commercial fields was reproduced in treatments with diazinon and captan mixtures in all experiments. The D iazinon A G 600 and Captec 4L mixture was the most severe and caused significantly more phytotoxic-

Extension specialist, Rutgers Blueberry and C ranberry Research and Extension Center, Chatsworth, N J 08019; e-mail: Polavarapu@aesop.rutgers.edu.

The cost of publishing this paper was defrayed in part by the payment of page charges. U nder postal regulations, this paper therefore must be hereby marked advertisement solely to indicate this fact. 
ity to fruit and leaves than individual treatments of Diazinon AG 600, Captec 4L or untreated control. Separation of diazinon and captan applications by $8 \mathrm{~h}$ significantly reduced phytotoxicity compared to mixture treatments. I njured fruit and leaves recovered over time and most treatments showed only a mild injury at the time of harvest. Phytotoxicity on fruit and leaves caused by D iazinon AG 600 and C aptec 4L mixture was significantly affected by application date with the earliest application causing the greatest injury. These data indicate that diazinon and captan mixtures cause phytotoxicity on highbush blueberries and therefore the two should not be applied in combination.

ighbush blueberries, are a major fruit crop in southern N ew Jersey. In 1998, blueberries were grown in more than 7,500 acres (3,000 ha) in $\mathrm{New}$ Jersey with a value of $\$ 28$ million (Tolomeo, 1999). Thirty-six states in the U nited States and six provinces in Canadagrow highbush blueberriescommercially on more than 40,000 acres (16,000 ha), and the total area planted in blueberries is expected to increase in N orth America (M oore, 1993).

A common practice in blueberry culture is to use combinations of insecticides and fungicides to reduce the number and cost of pesticide applications. This approach may lead to severe incompatibility and phytotoxicity problems if inappropriate combinations of chemicalsaretank-mixed. I t istherefore important to determine if a particular combination of chemicalsiscompatible and safe, before large-scale application. Thisisespecially necessary for new chemicals and formulations that have not been tested extensively in the field.

TheN ew J ersey blueberry industry usesmore diazinon than any other state in the U nited States (H amilton, 1996). Both emulsifiable concentrate and wettable powder formulations of diazinon have been in use for managing postbloom pests such as cranberry fruitworm (A crobasis vaccinii Riley), blueberry maggot ( $R$ hagoletis mendax Curran), sharp-nosed leafhopper (ScaphytopiusmagdalensisP rovancher), several species of aphids (Fimbriaphis fimbriata Richards and I Ilinoia pepperi M acGillivray), redbanded leafroller (A rgyrotaenia velutinana Walker), and obliquebanded leafroller (Choris- toneura rosaceana $\mathrm{H}$ arris) (Fiola et al., 1998). Growers also use captan (wettable powder and flowable formulations) from petal fall through harvest to protect fruit from various fruit rots, especially anthracnose fruit rot [Colle totrichum acutatum J.H. Simmonds or C. gloeosporioides (Penzig)]. Because diazinon and captan formulations are used over thesametimeperiod, growers often tank-mix these two pesticides on highbush blueberries.

D uring the 1997 growing season, a new water-based formulation of diazinon, D iazinon AG600 WBC (water-based concentrate), was introduced to $\mathrm{N}$ ew Jersey blueberries for the first time. D iazinon AG 600 WBC (N ovartis Crop Protection, Greensboro, N.C.) has been reported to have reduced odor, lower acute toxicity, and no organic solvents (Ciba Crop Protection, 1996). For these reasons, the water-based formulation has been suggested to have enhanced crop and environmental safety over thesolvent-based, emulsifiableconcentrate formulation ( $D$ iazinon $A G 500)$. TheD iazinon AG 600 formulation is slated to eventually replace Diazinon AG500.

D uring 1997 several growers observed severe phytotoxicity when tankmixes containing various formulations of diazinon and captan were used. Varieties such as 'Weymouth', 'Duke', 'Bluecrop', and 'Elliott' appeared to be equally susceptibleto phytotoxicity with thiscombination under field conditions. The phytotoxicity on fruit ranged from deep purple blotchesto circular depressions in areas where residues accumulated near the calyx end of the berries. on leaves, brownish purple spots were seen, especially on the underside of the leaf surface. T hesesymptomsweremost commonly associated with fields that received a combined application of Diazinon AG600 WBC and another relatively new captan formulation, Captec 4L (M icroflo, Lakeland, Fla).

In response to these growing concerns of suspected phytotoxicity, we initiated a comprehensive study to determine the relative phytotoxicity of combinations of several formulations of diazinon and captan, and to investigate theeffect of blueberry phenology on the phytotoxicity of Diazinon AG600 and Captec 4L mixture.

\section{Materials and methods}

General overvew. Experiments were conducted during the 1997 and 1998 growing seasons at Rutgers U niversity Blueberry and Cranberry Research and Extension Center, Chatsworth, N.J., on highbush blueberries planted in 1994. The bushes were 4 to 5 years old, about $5 \mathrm{ft}(1.5 \mathrm{~m})$ tall, and spaced $9 \times 4 \mathrm{ft}(2.7 \times 1.2 \mathrm{~m})$ apart on light sandy organic matter soil with $\mathrm{pH} 4.5$.

Two formulations of diazinon (D iazinon AG 600 and D iazinon 50W) and of captan (Captec 4L and Captan 80WP) were evaluated. The application rates of these formulations and an adjuvant, LI-700 (Loveland Industries, Greeley, C olo.) evaluated in this study are reported in Table 1. H ighest labeled rates were used in all experiments. The insecticidesand fungicideswere applied with aC O , pressurized backpack sprayer (Model T; R\&D Sprayers I nc., O pelousas, $L$ a.) equipped with a hollowconenozzle(T ee) et, 4VS; Spraying Systems Co., Wheaton, III.) calibrated to deliver $30 \mathrm{gal} /$ acre (280.6 $\left.\mathrm{L} \cdot \mathrm{ha}^{-1}\right)$. At each evaluation, samples of foliage and fruit were collected in polyethylene bags and transported to the laboratory for phytotoxicity determinations. A fruit or foliage cluster was considered to have phytotoxicity even if a single fruit or leaf in that cluster was injured due to phytotoxicity. Experiments 1 to 3 wereconducted during the 1997 season and Expts. 4 to 6 during the 1998 season. Except in Expts. 1 and 3 , each replication consisted of six bushes in a single row. Experiment 1 had five single-bush replications and in Expt. 3, each replication consisted of three bushes. There werethree replicationsin

Table 1. R ates of various formulations of diazinon, captan, and an adjuvant evaluated in the study.

\begin{tabular}{lcc}
\hline Formulation & R ate/acre & R ate/ha \\
\hline Diazinon AG600 WBC & $25.5 \mathrm{fl} \mathrm{oz}$ & $1,863 \mathrm{~mL}$ \\
Diazinon 50W & $2 \mathrm{lb}$ & $2.2 \mathrm{~kg}$ \\
Captan 80WP & $3.12 \mathrm{lb}$ & $3.5 \mathrm{~kg}$ \\
Captec 4L & $2.5 \mathrm{qt}$ & $5.8 \mathrm{~L}$ \\
LI 700 & $1 \mathrm{pt}$ & $1.2 \mathrm{~L}$
\end{tabular}


Expts. 2 and 3 and four replications in Expts. 4 to 6 . Treatments within a replication were separated by at least four bushes and replications were arranged 50 to $133.3 \mathrm{ft}$ ( 15 to $40 \mathrm{~m}$ ) apart. In all experiments, treatments were arranged in randomized complete block design. N one of the experimental plots received any other insecticide or fungicide applications except for the treatments reported in this study throughout the 1997 and 1998 seasons.

EXPERIMENT 1. The objective of the first experiment was to confirm and reproducethesymptomsof phytotoxicity caused by tank-mixes of Diazinon AG600 and Captec 4L observed in grower fields. Five bushes of the variety Elliott were treated on 11 June 1997 with Diazinon AG600 and Captec 4L mixture and five bushes of the same varietyserved as untreated controls. T en leaf and fruit clusters each were collected (five clustersfrom each sideof the bush) on 21 J uneand during harvest on 20 Aug. 1997.

EXPERIMENT 2. Combinations of diazinon (AG600 and 50W formulations) and captan (4L and 80WP formulations) mixtures were evaluated in this experiment conducted on the variety Bluecrop. T reatments were applied on 12 June 1997. Thirty fruit and leaf clusters each per replication ( 10 clusters each from threerandomly selected plants per replication) were sampled for phytotoxicity $7 \mathrm{~d}$ after treatment application. A second fruit evaluation ( 25 fruit clusters per replication) was also conducted on 13 July during harvest.

EXPERIMENT 3. In addition to the treatments in Expt. 2, a mixture comprising Diazinon AG600, Captec 4L, and an adjuvant, LI-700 was evaluated for phytotoxicity on 'Elliott'. Treatments were applied on 25 J une 1997. Twenty fruit and leaf clusters each per replication (10 clusters each from two randomly selected plants per replication) were sampled $8 d$ after treatment application on 3 July.

EXPERIMENT 4. Phytotoxicity of mixtures of diazinon formulations (AG600 or 50W) + Captec 4L was compared with phytotoxicityin sequential treatments of D iazinon AG 600 or Diazinon 50W application followed by an application of Captec 4L $8 \mathrm{~h}$ later. Treatments were applied on $18 \mathrm{M}$ ay 1998 to variety Weymouth. Thirty fruit and leaf clusters each per replication ( 10 clusters each from three randomly se- lected plants per replication) were sampled $9 \mathrm{~d}$ after treatment application to evaluate phytotoxicity.

EXPERIMENT 5. Phytotoxicity of mixtures of diazinon (AG600 or 50W) + Captan 80WP was compared with phytotoxicity in sequential treatments of D iazinon AG 600 or Diazinon 50W application followed by an application of Captan 80WP $8 \mathrm{~h}$ later. In addition, phytotoxicity was also evaluated on bushes that received Captec $4 \mathrm{~L}$ followed by Diazinon AG600 $8 \mathrm{~h}$ later. Treatments were applied on the variety Bluecrop on $26 \mathrm{M}$ ay 1998. Fruit and leaf clusters were sampled in the same manner as in Expt. 4 on 3 J une 1998, 8 $\mathrm{d}$ after treatment application.

EXPERIMENT 6. To determine the effect of blueberry phenology on the potential for phytotoxicity, thediazinon and captan combination that caused most acute phytotoxicity (Diazinon AG600 + Captec 4L) was applied at about 4- to 5-week intervals beginning at petal fall. T reatmentswere applied on the variety Elliott on $22 \mathrm{M}$ ay, 26 June, and 29 July. Fruit and leaf clusterswere sampled 5 to $8 \mathrm{~d}$ after each treatment application in the same manner as described under Expt. 4.

Statistical analysis. Data were analyzed by analysis of variance (AN O VA) or t tests using SAS system for windows, release 6.03 (SAS Institutel nc., 1988). D ataweretransformed before analysis using either square root (for number of clusters with phytotoxicity, number of berries, and berry weight) or arcsin (for percent phytotoxicity) transformations. U ntransformed dataare reported in tables and figuresas means and standard errors. M ean separation used Duncan's multiple range test $(P=0.05)$.

\section{Results}

Phytotoxicity similar to injury observed in commercial fields was evident in all experiments, usually within 24 to $36 \mathrm{~h}$ after the application of diazinon and captan mixtures. Phytotoxicity on berriesranged from deep purpleblotches to circular depressions, especially where residues have accumulated near the calyx end of the berries (Fig. 1). In most severe cases, the fruit had 2 to $3 \mathrm{~mm}$ (0.08 to 0.12 inch) diameter circular depressions filled with apparent pesticideresidue. B rownish purplespotswere seen especially on the underside of the leaf surface. Although phytotoxicity caused by either the diazinon (AG600 or 50W) or captan (4L or $80 \mathrm{WP}$ ) treatments was similar to injury caused by mixtures of diazinon and captan formulations, the degree of severity was much less in the nonmixture treatments. The most severe form of phytotoxicity (circular depressions on fruit) was not observed in the diazinon and captan treatments applied al one.

EXPERIMENT 1. The samples collected on $21 \mathrm{~J}$ une, $10 \mathrm{~d}$ after treatment application with D iazinon AG 600 and Captec $4 \mathrm{~L}$ mixture showed $100 \%$ phytotoxicity in both leaf and fruit clusters. Phytotoxicity was more pronounced in this experiment than in any other experiment in the study. Both green and ripe blueberries sampled at harvest exhibited severe phytotoxicity (Table 2). Weight of 100 mature berries was significantly lower in the D iazinon AG 600 + Captec $4 \mathrm{~L}$ treatment than in the untreated control. H owever, the number of berries per 10 clusters was similar in the two treatments. N early $100 \%$ of leaf clusters showed phytotoxicity at harvest.

EXPERIMENT 2. Fruit and leaf clusters showed significantly greater phytotoxicity in all treatments with diazinon and captan mixtures than in individual treatments of either Diazinon AG600 or Captec $4 \mathrm{~L}, 7 \mathrm{~d}$ after the treatment application (Table 3). Phytotoxicity on both fruit and leaves appeared to be more severe in the Diazinon AG600 and Captec $4 \mathrm{~L}$ mixture than in any other combinations of diazinon and captan formulations. About $10 \%$ of the berries showed somesymptoms of phytotoxicity in the Diazinon AG600 and Captec 4L mixture (Table 3). Significantly fewer fruit and leaf clusters exhibited phytotoxicity in the D iazinon $50 \mathrm{~W}$ + C aptec $4 \mathrm{~L}$ treatment than in the other two combination treatments with Diazinon AG600, C aptec 4L and Captan 80WP. There were no significant differences in the number of berries per 30 fruit clusters among the treatments. $M$ ixing of wettable powder formulations of diazinon (Diazinon 50W) and captan (Captan 80WP) resulted in the formation of a white sediment in the spray tank clogging the screen and nozzle. Consequently, this treatment was not applied at the calibrated rate. For this reason data were not collected from this treatment. No compatibility problems were evident in any other combination treatments.

Fewer berries had phytotoxicity (Table 4) at harvest than at $7 \mathrm{~d}$ after 

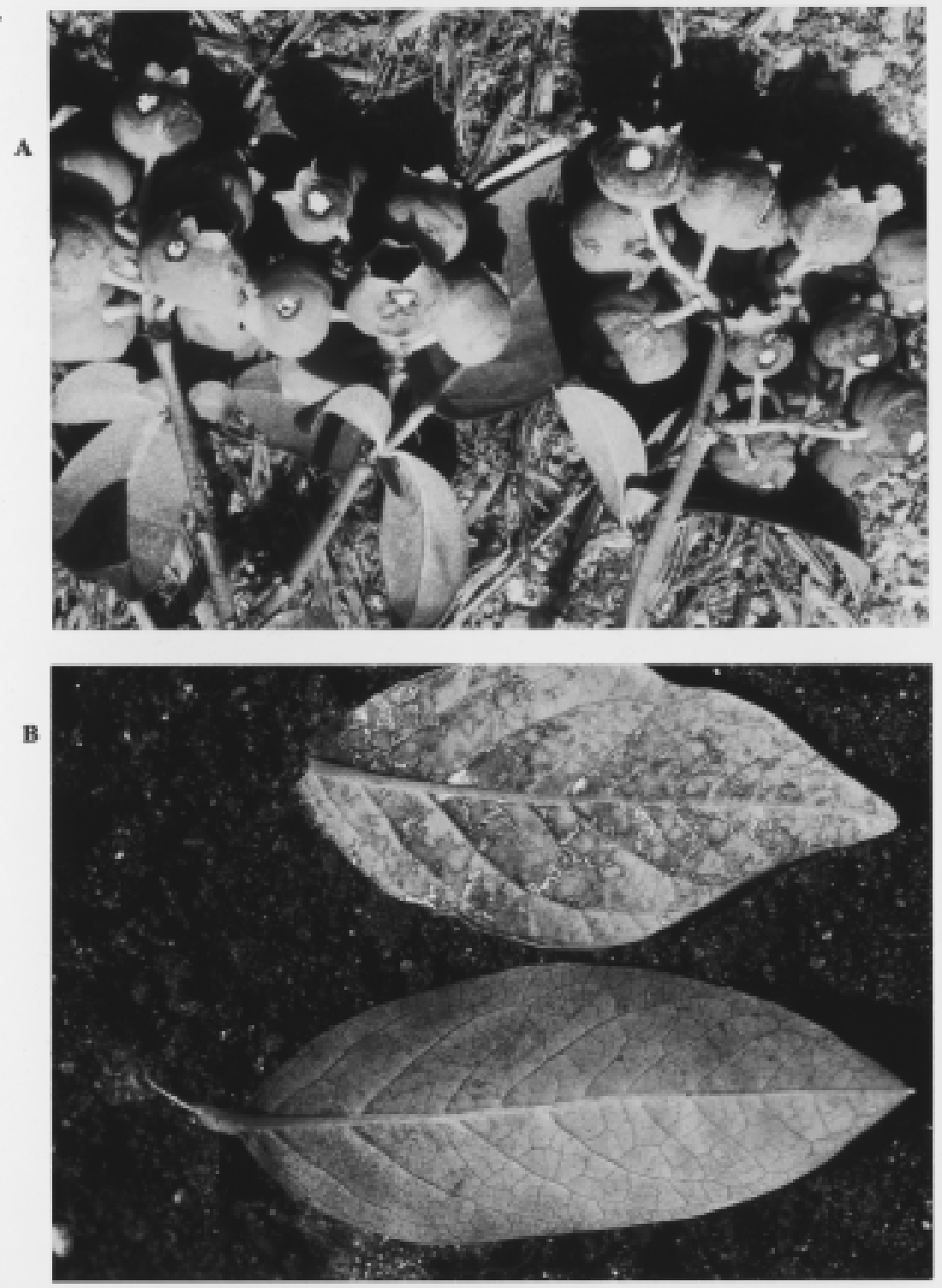

Fig. 1. Phytotoxicity of Diazinon $A G 600$ and $C$ aptec $4 L$ mixture (Expt. 1) on (A) fruit and (B) leaves. The bottom leaf in (B) is from untreated control.

treatment application in all treatments. Diazinon AG600 and Captec 4L mix- ture had the highest percentage of berries with phytotoxicity at harvest, but this effect was significant only among green berries (T able 4). T he number of berries per 25 clusters was not significantly different among the treatments. In all treatments, most of the berries at harvest had recovered from phytotoxic- ity and showed only minor blotches that were barely visible on the blueberry.

EXPERIMENT 3. The Diazinon AG 600 and Captec 4L mixture had the highest percentage of berries with phytotoxicity (Table 5). Phytotoxicity to leaves was evident in all treatment mixtures with diazinon and captan formulations. Phytotoxicity was also observed on fruit and leaves in treatments with diazinon and captan formulations applied alone. Captec $4 \mathrm{~L}$ was the most injurious to leaves among the four formulations applied separately. H owever, this injury was not as pronounced as seen in diazinon + captan combinations. Addition of spray adjuvant LI700 to D iazinon AG 600 and C aptec $4 \mathrm{~L}$ mixture appeared to enhance phytotoxicity to leaves, but not to the fruit. The number of berries per 20 fruit clusters was not significantly different among the treatments.

EXPERIMENT 4. Phytotoxicity similar to injury observed in 1997 (Expts. 1 to 3 ) was seen in treatments comprising diazinon formulations( $A G 600$ or $50 \mathrm{~W}$ ) and Captec $4 \mathrm{~L}$ mixtures. Consistent with the 1997 observations, phytotoxicity was most pronounced in D iazinon AG600 + Captec 4L treatment (T able 6); but unlike the 1997 experiments, a greater number of fruit clusters and percentage of fruit showed phytotoxicity than leaf clusters or percentage of leaves. Significantly lower numbers of fruit and leaf clusters or percentage of fruit and leaves showed phytotoxicity when Diazinon AG600 or Diazinon 50W applications and $C$ aptec $4 \mathrm{~L}$ applications were separated by an 8-h interval than their respective mixture treatments. Once again Captec 4L treatment alone showed slight phytotoxicity to fruit and leaf clusters.

EXPERIMENT 5. Phytotoxicity was the mildest in this experiment. Again, sequential application of captan and diazinon formulationswith an $8 \mathrm{~h}$ interval between individual treatment application significantly reduced the per-

T able 2. Phytotoxicity of Diazinon AG 600 W BC and C aptec 4L mixture to 'E lliott' blueberries at harvest, 1997 Expt. 1.

\begin{tabular}{|c|c|c|c|c|}
\hline \multirow[b]{2}{*}{ Treatment } & \multicolumn{2}{|c|}{$\begin{array}{l}\text { Berries with phytotoxicity (\%) } \\
\text { (mean } \pm \text { SE) }\end{array}$} & \multirow{2}{*}{$\begin{array}{c}\text { Berries } \\
\text { (no./10 clusters) } \\
\text { (mean } \pm \text { SE) }\end{array}$} & \multirow{2}{*}{$\begin{array}{c}\text { Wt of } \mathbf{1 0 0} \text { berries } \\
(\mathbf{g})^{\mathrm{y}} \\
(\text { mean } \pm \mathrm{SE})\end{array}$} \\
\hline & G reen ${ }^{2}$ & Blue & & \\
\hline $\begin{array}{l}\text { D iazinon AG } 600+\text { Captec } 4 \mathrm{~L} \\
\text { U ntreated }\end{array}$ & $\begin{array}{c}99.6 \pm 0.4 \mathrm{a} \\
0.0 \pm 0 \mathrm{~b} \\
* * * *\end{array}$ & $\begin{array}{c}97.1 \pm 1.7 \mathrm{a} \\
1.5 \pm 1.0 \mathrm{~b} \\
* * * *\end{array}$ & $\begin{array}{c}103 \pm 6.6 \\
99.2 \pm 5.0 \\
N S\end{array}$ & $\begin{array}{c}108.4 \pm 7.2 \mathrm{a} \\
145.0 \pm 11.2 \mathrm{~b} \\
*\end{array}$ \\
\hline
\end{tabular}

${ }^{2} \mathrm{G}$ reen and blue fruit were evaluated separately.

y $28.35 \mathrm{~g}=1.0 \mathrm{oz}$.

${ }_{\mathrm{Ns},, * * * * * *}$ onsignificant or significant at $\mathrm{P}<0.05,0.0001$, respectively. 
T able 3. Phytotoxicity of diazinon and captan on 'B luecrop' blueberries 7 d after treatment, 1997 Expt. 2.

\begin{tabular}{|c|c|c|c|c|}
\hline \multirow[b]{2}{*}{ T reatment } & \multicolumn{2}{|c|}{$\begin{array}{l}\text { Clusters with phytotoxicity } \\
\text { (no./30 clusters) (mean } \pm \text { SE) }\end{array}$} & \multirow{2}{*}{$\begin{array}{c}\text { Fruit with } \\
\text { phytotoxicity (\%) } \\
(\text { mean } \pm \mathrm{SE})^{\mathrm{y}}\end{array}$} & \multirow{2}{*}{$\begin{array}{c}\text { Berries } \\
\text { (no./30 clusters) } \\
\text { (mean } \pm \text { SE ) }\end{array}$} \\
\hline & Fruit clusters & Leaf clusters & & \\
\hline Captec 4L & $0.0 \pm 0 \mathrm{c}$ & $0.3 \pm 0.3 d$ & $0.0 \pm 0 \mathrm{c}$ & $233.0 \pm 10.0$ \\
\hline D iazinon AG 600 + Captec 4L & $9.3 \pm 1.9 \mathrm{a}$ & $22.7 \pm 1.2 \mathrm{a}$ & $10.3 \pm 2.3 a$ & $216.7 \pm 14.9$ \\
\hline Diazinon AG $600+C$ aptan 80WP & $7.7 \pm 1.3 \mathrm{a}$ & $16.0 \pm 2.0 \mathrm{~b}$ & $7.6 \pm 1.8 \mathrm{a}$ & $219.7 \pm 9.6$ \\
\hline \multirow[t]{2}{*}{ U ntreated control } & $0.0 \pm 0 \mathrm{c}$ & $0.0 \pm 0.0 \mathrm{~d}$ & $0.0 \pm 0 \mathrm{c}$ & $224.7 \pm 3.8$ \\
\hline & $* * * *$ & $* * * *$ & $* * * *$ & NS \\
\hline
\end{tabular}

${ }^{\mathrm{z} A}$ fruit or leaf cluster was considered to exhibit phytotoxicity when at least one berry or leaf in that cluster showed phytotoxicity.

yM eans within a column followed by different letters are significantly different (D uncan's multiple range test, $P=0.05$ ).

$\mathrm{NS},{ }^{* * * *} \mathrm{~N}$ onsignificant or significant at $\mathrm{P}<0.0001$, respectively.

T able 4. Phytotoxicity of diazinon and captan combinations on 'B luecrop' blueberries at harvest, 1997 Expt. 2.

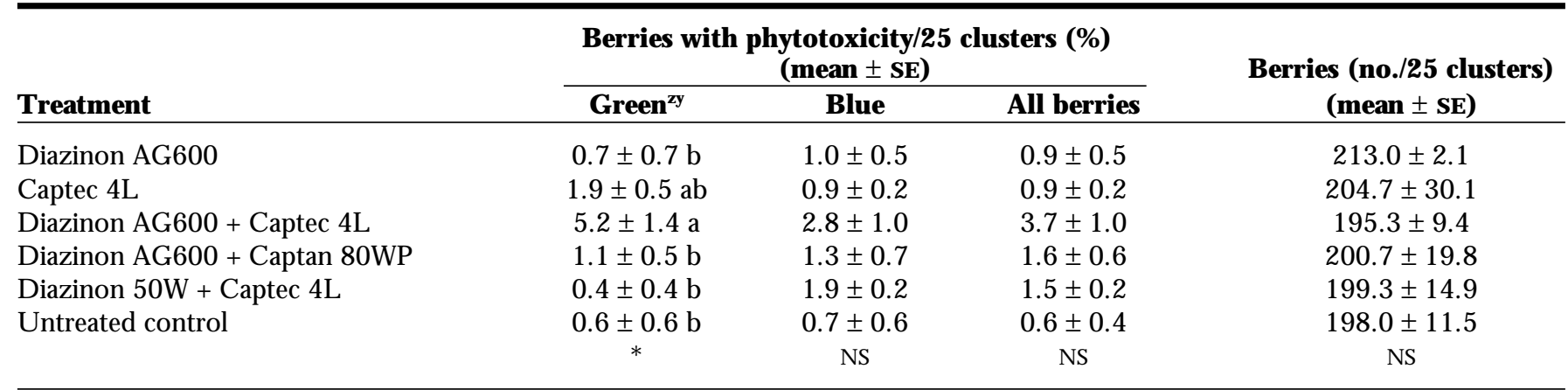

zM eans within a column followed by different letters are significantly different ( $D$ uncan's multiple range test, $P=0.05$ ).

y $G$ reen and blue fruit were evaluated separately.

$\mathrm{NS}^{*} \mathrm{~N}$ onsignificant or significant at $\mathrm{P}<0.05$.

T able 5. Phytotoxicity of diazinon and captan combinations on 'E lliott' blueberries, 1997 Expt. 3.

\begin{tabular}{|c|c|c|c|c|c|}
\hline \multirow[b]{2}{*}{ T reatment } & \multicolumn{2}{|c|}{$\begin{array}{l}\text { Clusters with phytotoxicity } \\
\text { (no./20 clusters) (mean } \pm \text { SE) }\end{array}$} & \multicolumn{2}{|c|}{$\begin{array}{l}\text { Phytotoxicity/20 clusters (\%) } \\
(\text { mean } \pm \text { SE })\end{array}$} & \multirow{2}{*}{$\begin{array}{c}\text { Berries } \\
\text { (no./20 clusters) } \\
\text { (mean } \pm \mathrm{SE} \text { ) }\end{array}$} \\
\hline & Fruit clusters ${ }^{y}$ & Leaf clusters ${ }^{y}$ & Fruit $^{y}$ & L eaves $^{y}$ & \\
\hline Diazinon AG600 & $0.0 \pm 0 \mathrm{c}$ & $4.0 \pm 1.5 \mathrm{c}$ & $0.0 \pm 0 \mathrm{c}$ & $3.7 \pm 1.1 \mathrm{de}$ & $169.7 \pm 18.2$ \\
\hline Diazinon 50W & $0.0 \pm 0 \mathrm{c}$ & $0.3 \pm 0.3 d$ & $0.0 \pm 0 \mathrm{c}$ & $0.9 \pm 0.9$ ef & $179.0 \pm 4$ \\
\hline Captec 4L & $0.3 \pm 0.3 b c$ & $14.0 \pm 1.5 \mathrm{~b}$ & $0.4 \pm 0.4 b c$ & $15.3 \pm 3.9 b c$ & $175.7 \pm 9$ \\
\hline Captan 80WP & $0.7 \pm 0.3 b c$ & $0.3 \pm 0.3 d$ & $0.9 \pm 0.4 b c$ & $0.3 \pm 0.3 f$ & $186.7 \pm 8.7$ \\
\hline $\begin{array}{l}\text { Diazinon AG } 600 \\
+ \text { C aptec } 4 \mathrm{~L}\end{array}$ & $4.0 \pm 2.5 \mathrm{a}$ & $20.0 \pm 0 a$ & $9.3 \pm 6.1 \mathrm{a}$ & $51.1 \pm 2.6 \mathrm{a}$ & $201.7 \pm 24.1$ \\
\hline $\begin{array}{l}\text { Diazinon AG } 600 \\
+ \text { Captan 80WP }\end{array}$ & $1.0 \pm 1 b c$ & $15.3 \pm 0.9 b$ & $1.1 \pm 1.1 \mathrm{bc}$ & $23.7 \pm 3.1 b$ & $156.3 \pm 12.5$ \\
\hline $\begin{array}{l}\text { Diazinon 50W } \\
+ \text { C aptec 4L }\end{array}$ & $1.0 \pm 0.6 \mathrm{bc}$ & $4.7 \pm 1.7 \mathrm{C}$ & $0.8 \pm 0.6 \mathrm{bc}$ & $8.1 \pm 4.7 \mathrm{~cd}$ & $169.3 \pm 12.5$ \\
\hline $\begin{array}{l}\text { Diazinon AG } 600 \\
+ \text { C aptec } 4 \mathrm{~L} \\
+ \text { LI } 700\end{array}$ & $2.0 \pm 0 a b$ & $19.7 \pm 0.3 \mathrm{a}$ & $3.0 \pm 1.0 \mathrm{ab}$ & $64.1 \pm 4.4 \mathrm{a}$ & $185.3 \pm 12$ \\
\hline U ntreated control & $\begin{array}{c}0.0 \pm 0 \mathrm{c} \\
*\end{array}$ & $\begin{array}{l}0.0 \pm 0.0 \mathrm{e} \\
* * * *\end{array}$ & $\begin{array}{c}0.0 \pm 0 \mathrm{c} \\
* *\end{array}$ & $\begin{array}{c}0.0 \pm 0 \mathrm{f} \\
* * * *\end{array}$ & $\begin{array}{c}180.6 \pm 7.2 \\
\text { NS }\end{array}$ \\
\hline
\end{tabular}

${ }^{2} \mathrm{~A}$ fruit or leaf cluster was considered to show phytotoxicity if at least one berry or leaf in that cluster had phytotoxicity. yM eans within a column followed by different letters are significantly different ( $D$ uncan's multiple range test, $P=0.05$ ). $\mathrm{Ns}, * * * *, * * * *^{*} \mathrm{~N}$ onsignificant, significant at $\mathrm{P}<0.05,0.01$, or 0.0001 , respectively.

centagefruit and leavesshowing phytotoxicity compared to the combined Diazinon AG600 + Captan 80WP applications(Table 7). Theorder of application of diazinon or captan formulations did not seem to affect phytotoxic- ity on fruit and leaves. This becomes evident by comparing the phytotoxicity in treatments where Diazinon AG600 or C aptec 4L wereapplied first followed by the application of the other formulation (C aptec 4L or D iazinon AG 600) 8 h later (Tables 6 and 7).

EXPERIMENT 6. Percentage of fruit and leaves showing phytotoxicity (Fig. 2) was significantly affected by treatment $(P<0.0001$, for both fruit and leaves; $F$ (statistic to determine differ- 
Table 6. Phytotoxicity of sequential treatments of diazinon and captan combinations on 'W eymouth' blueberries, 1998 Expt. 4.

\begin{tabular}{|c|c|c|c|c|}
\hline \multirow[b]{2}{*}{ Treatment } & \multicolumn{2}{|c|}{$\begin{array}{l}\text { C lusters with phytotoxicity } \\
\text { (no./30 clusters) }{ }^{z} \text { (mean } \pm \text { SE ) }\end{array}$} & \multicolumn{2}{|c|}{$\begin{array}{l}\text { Phytotoxicity/30 clusters (\%) } \\
\text { (mean } \pm \text { SE) }\end{array}$} \\
\hline & Fruit clusters $^{y}$ & Leaf clusters $^{y}$ & Fruit $^{y}$ & Leaves $^{y}$ \\
\hline Diazinon AG600 & $0.0 \pm 0 \mathrm{e}$ & $0.0 \pm 0 \mathrm{c}$ & $0.0 \pm 0 \mathrm{~b}$ & $0.0 \pm 0.0 \mathrm{c}$ \\
\hline Diazinon 50W & $0.3 \pm 0.3 \mathrm{de}$ & $0.3 \pm 0.3 c$ & $0.6 \pm 0.5 b$ & $0.2 \pm 0.2 c$ \\
\hline Captec 4L & $1.8 \pm 0.5 c$ & $8.0 \pm 1.5 b$ & $1.4 \pm 0.5 b$ & $6.7 \pm 1.9 c$ \\
\hline Diazinon AG600 + Captec 4L & $25.8 \pm 2.5 a$ & $14.5 \pm 2.0 \mathrm{a}$ & $64.7 \pm 12.2 \mathrm{a}$ & $16.2 \pm 3.8 \mathrm{a}$ \\
\hline Diazinon 50W + Captec 4L & $13.5 \pm 0.6 b$ & $7.2 \pm 0.9 b$ & $18.7 \pm 2.6 b$ & $5.4 \pm 0.7 b$ \\
\hline Diazinon AG600 first and Captec 4L $8 \mathrm{~h}$ later & $2.8 \pm 1.1 \mathrm{c}$ & $7.0 \pm 1.1 \mathrm{~b}$ & $3.0 \pm 1.5 b$ & $4.1 \pm 0.7 c$ \\
\hline Diazinon $50 \mathrm{~W}$ first and Captec 4L $8 \mathrm{~h}$ later & $1.5 \pm 0.6 \mathrm{~cd}$ & $5.0 \pm 1.5 b$ & $1.1 \pm 0.6 b$ & $3.2 \pm 1.4 \mathrm{c}$ \\
\hline U ntreated control & $\begin{array}{l}0.0 \pm 0 \mathrm{e} \\
* * * *\end{array}$ & $\begin{array}{l}0.0 \pm 0.0 \mathrm{c} \\
* * * *\end{array}$ & $\begin{array}{l}0.0 \pm 0 \mathrm{~b} \\
* * * *\end{array}$ & $\begin{array}{l}0.0 \pm 0 \mathrm{C} \\
* * * *\end{array}$ \\
\hline
\end{tabular}

${ }^{\mathrm{z} A}$ fruit or leaf cluster was considered to show phytotoxicity if at least one berry or leaf in that cluster showed phytotoxicity.

yM eans within a column followed by different letters are significantly different ( $D$ uncan's multiple range test, $P=0.05$ ).

*** Significant at $\mathrm{P}<0.0001$.

Table 7. Phytotoxicity of sequential treatments of diazinon and captan combinations on 'B luecrop' blueberries, 1998 Expt. 5.

\begin{tabular}{lcc}
\hline & \multicolumn{2}{c}{$\begin{array}{c}\text { Phytotoxicity/30clusters (\%) } \\
\text { (mean } \pm \text { SE ) }\end{array}$} \\
\cline { 2 - 3 } T reatment & Fruit $^{\mathbf{z}}$ & Leaves $^{\mathbf{2}}$ \\
\hline Captan 80WP & $0.2 \pm 0.2 \mathrm{~b}$ & $1.4 \pm 0.5 \mathrm{~b}$ \\
Diazinon AG600 + Captan 80WP & $18.1 \pm 3.1 \mathrm{a}$ & $9.0 \pm 1.3 \mathrm{a}$ \\
Captec 4L first and D iazinon AG600 8 h later & $2.2 \pm 1.8 \mathrm{~b}$ & $3.5 \pm 1.1 \mathrm{~b}$ \\
Captan 80WP first and Diazinon AG600 8 h later & $1.5 \pm 1.0 \mathrm{~b}$ & $1.8 \pm 0.8 \mathrm{~b}$ \\
Captan 80WP first and Diazinon 50W 8 h later & $0.1 \pm 0.1 \mathrm{~b}$ & $2.3 \pm 1.3 \mathrm{~b}$ \\
Untreated control & $0.0 \pm 0 \mathrm{~b}$ & $0.0 \pm 0 \mathrm{C}$ \\
& $* * *$ & $* * *$
\end{tabular}

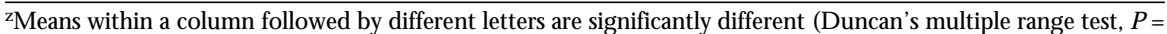
$0.05)$.

${ }^{* * *}$ Significant at $\mathrm{P}<0.001$

encesamong treatment means) $=165.3$, and 139.8 , respectively for fruit and leaves; $1 \mathrm{df}$ (treatment or numerator), $23 \mathrm{df}$ (error or denominator)) and application dates $(P<0.001$ for both fruit and leaves; $F=51.2$ and 9.8 , respectively, for fruit and leaves; 2, $23 \mathrm{df}$ ). The interaction of treatment and application date on percentage of fruit and leaves exhibiting phytotoxicity was also significant $(P<0.0001 ; F=64.3 ; 2,23 \mathrm{df}$, for fruit, and $P<0.001 ; F=9.8 ; 2,23$ $\mathrm{df}$, for leaves). A significantly greater percentage of fruit and leaves showed phytotoxicity in Diazinon AG600 + Captec 4L treatment applied on 22 $M$ ay, immediately following petal fall, than in the same treatments applied approximately at 5-week intervals in June and July (Fig. 2). A greater percentage of leaves exhibited phytotoxicity in Diazinon AG600 + Captec 4L treatment applied on 29 J uly than in the same treatment applied on 26 J une.

\section{Discussion}

Phytotoxicityobserved in commer- cial blueberries during the 1997 season was reproduced in all six experiments reported here when formulations of diazinon and captan were applied together. Phytotoxicity on fruit and foliage was the same across years and varieties. Phytotoxicity in D iazinon AG 600 + C aptec $4 \mathrm{~L}$ treatmentswasmoresevere in 1997 than in 1998, most probably related to frost events during spring. A higher percentage of leaf injury was evident in experiments conducted during the 1997 season than in experimentsconducted during 1998, whereas fruit injury was either comparable or somewhat higher in the 1998 experiments (Tables 1 to 6 , and Fig. 2). The relative tolerance of fruit and leaves to frost injury and how this interacts with phytotoxicity of diazinon and captan mixtures is unclear at present.

In this study there was significant fruit injury at harvest caused by several different mixtures of diazinon + captan formulations, especially Diazinon AG600 + Captec 4L. Some of these berries were not suitable for fresh fruit market. With this level of injury, a commercial grower may either haveto spend additional labor and money to cull injured fruit or sell fruit for the processed fruit market.

Although in many diazinon and captan treatments there was a large percentage of fruit and leaves exhibiting phytotoxicity a few days after the treatment application, the fruit and leaves generally recovered remarkably well and showed very little injury at the time of harvest (e.g., Tables 3 versus 4). This recovery was even greater in experiments that were treated later in the season (e.g., Expt. 3). In Expt. 1, however, the fruit injury was so severe that

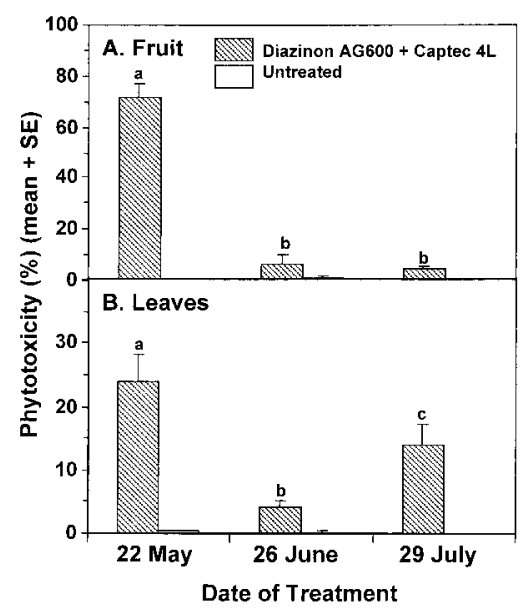

Fig. 2. The effect of application date of Diazinon AG 600 and C aptec 4L mixture on percentage phytotoxicity on (A) fruit and (B) leaves of highbush blueberries. E rror bars represent \pm 1 SE of the mean. Bars with different letters are significantly different using D uncan's multiple range test ( $P \leq \mathbf{0 . 0 5}$ ). 
theinjured fruit weresmaller and weight per 100 berries was significantly lower in the Diazinon AG600 + Captec 4L treatment than in theuntreated control. In none of the experiments was the number of berriesper cluster affected by phytotoxicity of diazinon and captan formulations.

Diazinon (AG600 and 50W) and captan (4L and 80WP) formulations applied alone caused mild phytotoxicity in a small percentage of fruit and leaves. Of these four formulations, Captec $4 \mathrm{~L}$ applied alone caused consistently more phytotoxicity, especially to leaves, than the other three formulations. In most cases, however, the injury was very superficial and fruit and leaves more or less completely recovered from phytotoxicity by harvest time. Among the combination treatments, D iazinon AG $600+C$ aptec $4 \mathrm{~L}$ caused significantly more phytotoxicity than Diazinon AG600 +C aptan 80WP or Diazinon 50W + Captec 4L. Diazinon $50 \mathrm{~W}+\mathrm{C}$ aptec $4 \mathrm{~L}$ wasleast phytotoxicand Diazinon AG600 + Captan 80WP was intermediate (Table 5). Diazinon 50W + Captan 80WP is probably thesafest of the four combinations, but these two formulations were not compatible in our study. A few growerscontinueto usethiscombination with larger ground equipment with adequate agitation and at higher pressure. Separation of diazinon and captan applications by an $8 \mathrm{~h}$ interval was sufficient to reduce phytotoxicity levels to those observed with diazinon or captan alone (Tables 6 and 7). The order of application of diazinon and captan did not affect phytotoxicity. Blueberrygrowers use both captan and diazinon over a 4- to 8-week period beginning at petal fall through harvest. If these formulationsare required to beused at the same time, thesedatasuggest that they should be applied at least $8 \mathrm{~h}$ apart.

Susceptibilityto phytotoxicityappears to be affected by the crop phenology. Leaves and fruit early in the season are more prone to injury than later in the season (Fig. 2). Younger shootsand smaller fruit may havea less well developed cuticle that may allow the penetration of compoundsin theformulation, causing phytotoxicity. A significantly higher percentage of leaves showed phytotoxicity on 29 J uly than 26 June (Fig. 2). D uring the course of the growing season thehighbush blueberry produces multiple flushes of vegetative growth (Eck, 1988). As many as five flushes of growth on an individual shoot have been recorded (Gough et al., 1978). There were many more younger shoots in the samplescollected after the 29 J uly application than in samples collected after the 26 J une application (personal observations). This may explain the higher percentage of leaves showing phytotoxicity following Diazinon AG600 + Captec 4L application on 29 July than after the 26 J une application.

Based on these studies, tank-mixing of diazinon and captan formulations for use on highbush blueberries is not recommended. The Diazinon AG600 and Diazinon 50W labels have been recently modified to reflect this recommendation. The Captec $4 \mathrm{~L}$ label already prohibits mixing with other flowable formulations. G rowers should be made aware of these label changes so that tank-mixes of diazinon and captan formulations are avoided.

Extension personnel should increase awareness among growers regarding the potential for phytotoxicity with tank-mixtures. This is especially important considering that a safe mixture tested one year may still cause phytotoxicity in other years. Growers should always ascertain the safety of tank-mixes by testing with actual equipment on a small test area before using the mixture on a larger area.

\section{Literature cited}

Ciba Crop Protection. 1996. N ew and improved diazinon. Ciba Crop Protection, Greensboro, N.C.

Eck, P. 1988. Blueberry science. Rutgers Univ. Press, N ew Brunswick, N.J.

Fiola, J., P.V. O udemans, and S. Polavarapu. 1998. Small fruit pest control recommendations for N ew Jersey, p. SmF 3-9. In: A. Gould and G.C.H amilton (eds.). Pesticides for $\mathrm{N}$ ew Jersey 1998. Rutgers Coop. Ext. Publ. E045N, Rutgers U niv.

Gough, R.E., V.G. Shutak, and R.L. H auke. 1978. Growth and development of highbush blueberry. I. Vegetative growth. J. Amer. Soc. H ort. Sci. 103:94-97.

H amilton, G.C. 1996. Blueberries, p. 3-7. In: G.C. H amilton (ed.). N ational agricultural pesticide impact assessment program (NAPIAP) background document on diazinon use and benefits on selected agricultural crops. NAPIAP, U SDA.

M oore, J.N. 1993. The blueberry industry of N orth America. Acta H ort. 346:15-27.

SAS Institute. 1988. SAS/ STAT user's guide, version 6.03. SAS Institute, Cary, N.C.

Tolomeo, V. 1999. 1998 Blueberry statistics. N .J. Agr. Stat. Serv., Trenton. 